\title{
FIRST NATURAL HELMINTH INFECTION IN THE MONGOLIAN GERBIL Meriones unguiculatus (RODENTIA, MURIDAE), PARASITIZED WITH Dentostomella translucida (NEMATODA, HETEROXYNEMATIDAE) IN THE NEOTROPICAL REGION
}

\author{
PINTO, R. M., GOMES, D. C., MENEZES, R. C., MUNIZ-PEREIRA, L. C. \\ and NORONHA, D. \\ Laboratório de Helmintos Parasitos de Vertebrados, Departamento de Helmintologia, Instituto Oswaldo Cruz, \\ Av. Brasil, 4365, CEP 21045-900, Rio de Janeiro, RJ, Brazil \\ Received January 14, 2002 - Accepted May 20, 2002 - Distribuited February 28, 2003
}

(With 1 figure)

Taking into account the importance laboratory and pet animals have (Robertson et al., 2000; Pinto et al., 2001b) this investigation was scheduled to add new information to previous Brazilian reports of helminths recovered from these hosts (Pinto et al., 1994, 2001a, b, 2002). The present results are related to the study of a nematode species infecting pet shop gerbils in Brazil. Ten male adult domestic Mongolian gerbils (Meriones unguiculatus) weight 46.0 to 75.0 $\mathrm{g}$, aged 6 to 9 weeks, were purchased from a pet shop in Rio de Janeiro, State of Rio de Janeiro, Brazil, in August 1997. Husbandry of animals, sacrifice, recovery of parasites and processing of worms for study have been reported elsewhere (Pinto et al., 2001a, b, 2002).

Dentostomella translucida Schulz \& Krepkorgorskaya, 1932 (Oxyuroidea, Heteroxynematidae). Prevalence, range of infection and mean intensity of the parasite were of $100 \%, 2-13$ and 6.9, respectively. Morphometrics are based on 10 adult specimens, five males and five females.

Males: body 12.5-15.3 (13.84) long, 0.27-0.32 (0.28) wide. Head with 4 small submedian papillae and two external circle amphids, and 6 internal circle small papillae. Lips absent, buccal cavity shalow, with 5 teeth per esophageal sector. Esophagus 0.270.35 (0.30) long. Nerve ring 0.13-0.20 (0.16) from the anterior end. Excretory pore not observed. Caudal alae wide, strong, with plaquelike markings on the ventral surface. Spicule single, 0.28-0.34 (0.30) long, with the tip bluntly rounded in lateral view, bifid in ventral view. Four pairs of caudal papillae: 1 large ad-cloacal pair, 1 pair on the cloacal protuberance posterior to cloaca, followed by two pairs of postcloacal papillae, from the posterior extremity. Cloacal aperture $0.32-0.38(0.34)$ from the posterior end.
Females: body 19.0-25.0 (21.8) long, 0.420.53 (0.48) wide. Head the same as described for the males. Esophagus 0.30-0.33 (0.32) long. Nerve ring $0.20-0.25(0.22)$ from the anterior end. Excretory pore not observed. Vulvar aperture 9.513.0 (11.48) from the anterior extremity. Opisthodelphic. Ovijector directed anteriorly in part, reflexes and continuing posteriorly as an unpaired uterine tube. Eggs oval, asymmetrical, 0.089-0.15 (0.10) long, 0.030-0.046 (0.038) wide. Rectum 0.20$0.28(0.24)$ long with strongly muscular walls. Anus 0.65-0.75 (0.70) from the posterior end.

Host: Meriones unguiculatus (MilneEdwards, 1867); site of infection: anterior portion of the small intestine; localities: pet shop in Rio de Janeiro (maintainance) and Magé (source), State of Rio de Janeiro, Brazil; voucher specimens: Helminthological Collection of the Oswaldo Cruz Institute n. 34579 a-j (a-e, males; f-j, females), 34580 a-d (males), whole mounts; 34655 (males and females), 34686 (males), wet material.

Mongolian gerbils, Meriones unguiculatus, quite recently introduced in Brazilian pet shops, had never been investigated for helminths in our country (Brazil) and the animals studied here, yielded burdens of the nematode Dentostomella translucida. This species was proposed by Schulz \& Krepkorgorskaya (1932) on the basis of specimens recovered from the great gerbil Rhombomys opimus Lich., collected in Kazakhstan. Later, D. translucida was referred in North America (Wightman et al., 1978; Pilitt \& Wightman, 1979) and in Turkey (Burgu et al., 1992).

Present data on Dentostomella translucida represent the first report of the species naturally infecting gerbils in the Neotropical region. 

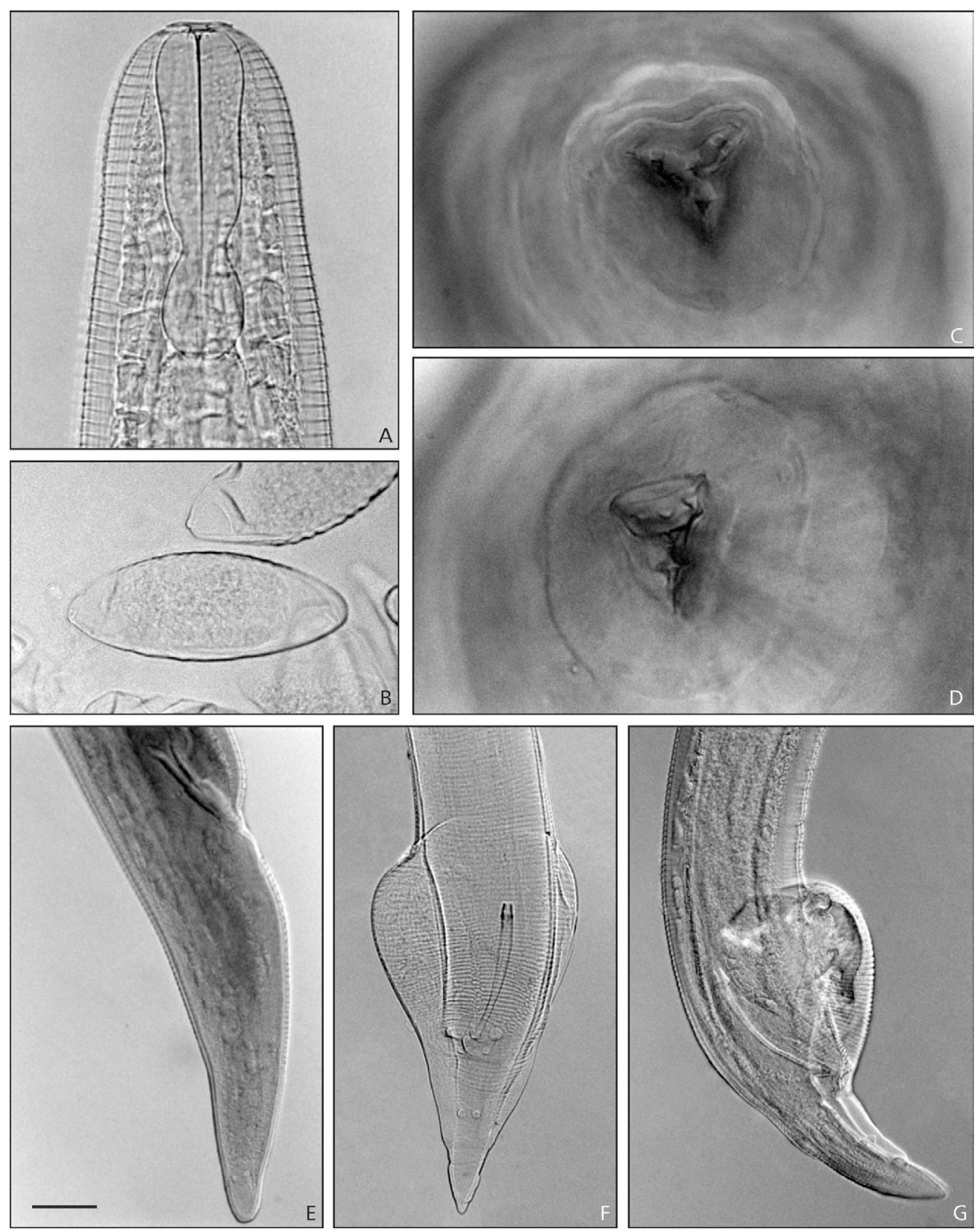

Fig. 1 - Dentostomella translucida. A. Anterior portion of male, lateral view. Scale bar: $0.07 \mathrm{~mm}$. B. Eggs in utero. Scale bar: $0.02 \mathrm{~mm}$. C. Head of female, showing the oral papillae, en face view. Scale bar: $0.02 \mathrm{~mm}$. D. Head of female, showing the esophageal teeth, en face view. Scale bar: $0.02 \mathrm{~mm}$. E. Posterior extremity of female, lateral view. Scale bar: 0.1 $\mathrm{mm}$. F. Posterior extremity of male, ventral view. Scale bar: $0.1 \mathrm{~mm}$. G. posterior extremity of male, lateral view. Scale bar: $0.1 \mathrm{~mm}$. Bar of Fig. E, common to Figs. A-D, F, G. 


\section{REFERENCES}

BURGU, A., ALABAY, M. \& OGE, H., 1992, Gerbilde (Meriones unguiculatus) Dentostomella translucida Schulz ve Krepkorgorskaja, 1932. Vet. Fak. Dergisi, 39(1/2): 291299.

PILITT, P. A. \& WIGHTMAN, S. R., 1979, A redescription of Dentostomella translucida Shulz and Krepkorgorskaja, 1932 (Nematoda: Heteroneximatidae) parasite of domestic Mongolian gerbils, Meriones unguiculatus Milne-Edwards. Proc. Helminthol. Soc. Wash., 46(1): $36-42$.

PINTO, R. M., GOMES, D. C., MUNIZ-PEREIRA, L. C. \& NORONHA, D., 2002, Helminth fauna of the guinea pig (Cavia porcellus L., 1758) in Brazil. Revta Bras. Zool., (in press).

PINTO, R. M., GONÇALVES, L., NORONHA, D. \& GOMES, D. C., 2001a, Worm burdens in outbred and inbred laboratory rats with morphometric data on Syphacia muris (Yamaguti, 1935) Yamaguti, 1941 (Nematoda Oxyuroidea). Mem. Inst. Oswaldo Cruz, 96(1): 133-136.
PINTO, R. M., GONÇALVES, L., GOMES, D. C. \& NORONHA, D., 2001b, Helminth fauna of the golden hamster Mesocricetus auratus in Brazil. Contemp. Top. Lab. Anim. Sci., 4O(2): 21-26.

PINTO, R. M., VICENTE, J. J., NORONHA, D., GONÇALVES, L. \& GOMES, D. C., 1994, Helminth parasites of conventionally maintained laboratory mice. Mem. Inst. Oswaldo Cruz, 89(1): 33-40.

ROBERTSON, I. D., IRWIN, P. J., LYMBERY, A. J. \& THOMPSON, R. C. A., 2000, The role of companion animals in the emergence of parasitic zoonoses. Int. J. Parasitol., 30: 1369-1377.

SCHULZ, R. E. \& KREPKORGORSKAYA, T. A., 1932, Dentostomella translucida $\mathrm{n}$. gen., n. sp. (Nematoda, Oxyurinae) aus einem Nagetier (Rhombomys opimus Licht). Zool. Anz., 97: 330-334.

WIGHTMAN, S. R., PILITT, P. A. \& WAGNER, J. E., 1978, Dentostomella translucida in the Mongolian gerbil (Meriones unguiculatus). Lab. Anim. Sci., 28(3): 290296. 